\title{
CO-EVOLUTION, SUSTAINABLE TOURISM AND PROTECTED AREAS
}

\author{
VICTORIA L. MELLON \\ Sheffield Hallam University, UK
}

\begin{abstract}
This paper explores the concept of co-evolution and its role in achieving a greater understanding of sustainable tourism in the context of protected areas. Adopting a co-evolutionary perspective has potential to be a fertile ground for studying governance and policy of Sustainable Development. In the context of protected areas where social and ecological systems run parallel with each other, and where Sustainable Development has become a key objective, co-evolutionary development may be expected. Therefore, this exploration of sustainable tourism policy and governance in a protected area through a co-evolutionary lens uncovers a wide range of linkages and relationships to other policies, internal and external influences and the protected area's historical context. The paper reveals how sustainable tourism policies in the Lake District National Park, England, developed incrementally and gradually over a period of 20 years and were often reformulated and reframed during this time scale. Similarly, the paper also discusses findings from research within the Peak District National Park Authority, England which reveal how drivers for sustainable tourism increased greater partnership working and how policies for sustainable development and sustainable tourism "co-evolved" during the studied period. The paper draws attention to the value of adopting a co-evolutionary approach to sustainable tourism research, particularly if institutions are operating in an environment where the ability to learn and understand the complexity of sustainable tourism and can contribute to their wider goals of Sustainable Development.
\end{abstract}

Keywords: protected area tourism, sustainable tourism, co-evolution, tourism governance.

\section{INTRODUCTION}

This paper aims to review and reflect on co-evolution occurrences within two UK based protected areas. It considers how co-evolution has arose through greater emphasis on sustainable tourism and sustainable development in the Lake District National Park and the Peak District National Park.

Protected areas are increasingly being expected to incorporate wider goals into their management remit, this is particularly true with parks falling into the International Union for Conservation Nature, Category V [1], [2]. Literature suggests there is greater emphasis in these parks, particularly on developing socio-economic wellbeing of its communities, wider actor engagement and sustainable development and subsequently through sustainable tourism [3], [4].

Therefore, such protected area contexts provide an interesting and diverse policy milieu which are ripe for the study of and application of the co-evolution perspective. In addition to trends towards greater integration through sustainable tourism, institutions also play a key role in the sustainable tourism mix and their temporal nature can also reveal insights through the co-evolution perspective.

This paper reflects on $\mathrm{PhD}$ study which focuses on the evolution of sustainable tourism in protected areas over a 15-20 year period. The broader $\mathrm{PhD}$ research incorporates broader theories and findings relating to path dependency, historical institutionalism and coevolution. The findings from the paper are reflections from the two case studies which have formed the basis of research for three articles (two published and one in review). This paper has allowed for greater consideration of specific findings relating to co-evolution and 
sustainable tourism within the broader research strategy, and provides a review of the how co-evolution has occurred in the two UK case studies.

\section{LITERATURE REVIEW}

\subsection{Co-evolution and governance, sustainable development}

Co-evolutionary perspectives provided interesting grounds for exploring sustainable development and its governance [5], [6]. Norgaard [6, p. 161] suggests in a biological context, coevolution refers to "reciprocal responses" between species however he asserts that the "same concept can be broadened to encompass any ongoing feedback process between two evolving systems, including social and ecological systems".

More specifically co-evolution may be viewed as a series of relationships which involve different sub-systems which are reciprocally inter-related and mutually constituting [5]. Such co-evolution processes have been noted by researchers between varying sub-systems and scales, such as between actors and structures by Giddens (1984), between technology and governance by Von Tunzelmann [7], and between ecology, economy and society by Norgaard [6].

The co-evolutionary development over time of policy areas involves them helping to shape each other but not to determine each other. Sustainable tourism policies, for example, can be affected by, but are not fully determined by, policy developments which are not directly concerned with either tourism or sustainable development. Similarly, policies targeted at sustainable tourism can influence other related policy fields. A co-evolutionary view is "important for thinking about governance for sustainable development", due to the complex interdependent relationships involved in this broad policy field [5, p. 2], [6].

The different sub-systems and scales associated with public policies have a relative autonomy, and are partially independent. Economic policies, for example, can co-evolve with environmental policies, where they help to shape rather than determine the character of each other. The co-evolutionary processes may also be between specific policies and macro-scale societal events, changes and influences. In the context of changes in waste management policy, for example, Kemp et al. [5, p. 7] argue that this "is best understood as a process of co-evolution of the waste management subsystem and societal values and beliefs (a society growing conscious of waste problems and hostile to landfill sites)". Co-evolutionary relationships may also occur between other sub-systems, such as between policies for sustainable development and the organisational arrangements established to apply the policies.

\subsection{Tourism and co-evolution}

Tourism and co-evolution perspectives are increasingly gaining traction in tourism research. When these concepts are used in tourism research they are often drawn from research in the academic field of "evolutionary economic geography" [8], [9]. Some of these recent studies of tourism and temporal change recognise that path creation and path dependence are better understood if they are not seen as binary or separate categories [10]-[12]. Brouder and Fullerton [13, p. 152], for example, note how incremental path creating changes have occurred in the established tourism development path in Niagara, Canada, and that these "new paths co-evolve with the dominant tourism paths". In their study of Whistler, Canada, Gill and Williams $[11$, p. 48] similarly argue that there is "contestation ... between path- 
dependent forces that embody lock-in to established economic, political and social institutions, and path-creation forces".

Here, the research reflects on co-evolutionary perspectives explored by Bramwell and Mellon [14] and Bramwell and Cox [15] in the context of sustainable tourism policies in protected areas and in protected area institutional arrangements.

\section{METHODOLOGY}

The paper explores co-evolution and sustainable tourism in two protected area contexts set in the UK. First, the policies relating to sustainable tourism for the Lake District National Park, a developed world, Category V protected area, over a period of two decades (from the late 1980s to 2012) were considered. This Park in north-west England was designated in 1951. It is the largest national park in England and Wales, covering 2292 square kilometres, and it is characterised by lakes, mountains, and a short coastal stretch [16]. It has 40,800 residents and much of the land is privately owned, often by farmers.

The policies relevant to sustainable tourism are not examined in isolation, rather they were examined for potential relationships with the wider policy context and other broader policies. Over 30 policy documents were evaluated, representing over 1,500 pages of text. They included Park Authority national park plans, policy discussion documents, performance reviews and economic and business reviews, as well as other relevant policy and evaluation documents produced by other agencies. Semi-structured interviews were also conducted with 12 actors selected to represent the key agencies and interests, with individual respondents chosen as they had significant experience of the issues. These were two National Park employees, two Cumbria Tourism staff, two local government employees, one staff member of a local sustainable tourism organisation (Nurture Lakeland, previously the Tourism and Conservation Partnership), and five respondents who worked in the Park's tourism industry. Respondents were asked about issues and trends suggested by the review of academic literature and by the Park's policy documents. The interviews were semi-structured, they explored relevant policies and relationships in the Park, they lasted between 35 and 90 minutes, and they were recorded and transcribed.

The second case study for the research relates to the broader research strategy of focussing on the temporal evolution of two institutions established to reduce tensions between outdoor recreation, tourism and environmental protection at Stanage in the UK's Peak District National Park (also a Category V designated park located in central England). Stanage and North Lees estate (here subsequently shortened to Stanage estate) is an upland area which is owned by the Park Authority and is of outstanding landscape value and of international importance for its heather moorland and bog ecology. The estate is popular with hill walkers, rock climbers, bird watchers and off-road vehicle drivers, with an estimated over half a million visitors in 2002 [17]. There are tensions between recreation, tourism and the area's important environmental/ecological qualities, such as between rock climbing and the protection of bird-nesting habitats, especially during the bird-breeding season.

The Park Authority established the Stanage Forum and its associated Steering Group, and it asked these institutions to develop and apply a new estate management plan. Decisions about the estate were formally approved at the annual Forum meeting, which was open to the general public. Its associated Steering Group was a partnership organisation made up of interest group representatives, and it met more regularly than the Forum. It coordinated the drawing up and implementation of the estate management plan, and it reported to the annual Forum. The study here assesses how the Forum and Steering Group first emerged in 2000 and then evolved over the period to 2011 . 
Methods included documents analysis from the Stanage Forum and Steering Group's management plan, reports and minutes of meetings. Second, observation took place by attending several Forum meetings and Steering Group meetings. Third, use was made of academic studies by Tim Richardson on the early work of the two organisations, studies that used interviews, internal documents and observation of meetings to examine issues of consultative democracy [18]-[21].

Fourth, semi-structured interviews that were conducted in 2007 and also in 2011 with key actors associated with the Forum and Steering Group. The six interviewees in 2007, including four Steering Group members, were: two national park staff with management responsibilities for Stanage, a climbing representative, a nearby resident, a national park committee member, and a top-tier national park staff member. In 2011 the nine interviewees, including seven Steering Group members, were four recreation group representatives, a nearby resident representative, a conservation group representative, and three national park staff with management responsibilities for Stanage. Four respondents were interviewed in both 2007 and 2011. The interviews lasted an average of 62 minutes in 2007 and 73 minutes in 2011.

The researchers actively sought to confirm and disconfirm ideas and to remain open to new interpretations. The continuing dialogue between the collected information and the study's conceptual ideas on evolving institutional paths followed Miles and Huberman's [22, p. 10] guidelines on qualitative data reduction, as a process of "selecting, focusing, simplifying, abstracting, and/or transforming" information in order to develop conceptual interpretations.

\section{FINDINGS}

\subsection{Sustainable development policies, directly affecting sustainable} tourism policies, leading to co-evolution

In both the Lake District and Peak District, there was evidence of co-evolution between sustainable development policies and the broader aims and objectives of the protected areas, which may have then influenced the direction of sustainable tourism. The LDNPA offer that sustainable development principles were to be promoted, enhanced and incorporated into the wider remit for environment, economic and community well-being and to ensure the impact of one has positive benefits for another [23] in turn, tourism policies and actions were interconnected to these aims and co-evolved with sustainable development policies. A Lake District National Park Authority employee suggested there had "been a gradual evolution in planning towards sustainable development over the last 15 years", and that sustainability policies had "filtered through to tourism", this meant the park authority were now more flexible in their planning process for tourism enterprises to establish greater sustainability. A vision for the Peak District, also acknowledges the 'links' and 'interwoven' nature of people, the environment, and the economy. Integration and understanding of all three is considered essential for more sustainable outcomes [24]. The PDNPA further recognises the role of sustainable tourism in this integrative approach, as it can provide 'key opportunities' for achieving the goal of sustainability [24]. Indeed, sustainable tourism relies upon such integration with other policy domains for its full realisation. For example, the PDNPA highlights how its 2003 Recreation Strategy aims to build on and cut across other broad policies fields including the sustainable tourism strategy. There is an expectancy that the strategies will be related and operate in integrative fashion. The co-evolution between the sustainable development and sustainable tourism is perhaps an obvious one, however it does 
provide insights into how sustainable development becomes imbedded into different policy domains, this conceivably also gives weight to Norgaard's notion that co-evolution is developmental and occurs through necessity to maintain the social and ecological systems in their present state [6, p. 161].

4.2 Policies relating to widening participation and actor engagement fostering co-evolution

Co-evolution between sustainable development frameworks and agreements to widen actor participation and sustainable tourism seemingly occurred in the Lake District National Park.

Protected areas are often arenas with conflict and contentious relationships over differing perceptions and ideologies over their use [25]. In both protected areas, historical conflict was present between numerous stakeholders and the park authorities. Over the study period of both parks, there was a move towards greater participation and collaboration amongst business communities, user groups and the authorities themselves.

In the Lake District National Park, pressure from an external review revealed that greater cooperation and understanding was required to improve relationships between the authority and its business community (historical conflict existed over the reduction of speed limits on a popular lake used by numerous tourists and private speed boats organisations). The park authority strived to improve working relationships by engaging and collaborating with the business community through mechanisms, such as a business task forum and the development of a broader working partnership group. This greater involvement of the local business community may have provided more rationale and reason to develop further social and economic outcomes. One park document specified "More emphasis is given to the role of partnerships in achieving National Park purposes and fostering economic and social wellbeing" [26], and more recently, one interviewee commented that there had 'much more positive environment' and the park authority had engaged in more listening and consulting.

In the context of wider actor engagement, the sustainable development framework encouraged a greater drive towards improving relationships with local communities. Management plans and interviewees concurrently offered that engagement with local communities was essential in the quest for greater sustainable development [23]. The desire to improve working relationships with local communities and the need to adhere to sustainable development policies, led to greater involvement by the business community, a fair proportion of which are directly connected to the tourism industry. This increased involvement by the business community provided an impetus for policies and actions relating to improving local socio-economic well-being via the tourism industry and through the prism of sustainable tourism. Thus, the Park Authority's tourism-related policies could co-evolve in relation to wider pressure for better relationships between the Authority and community and business actors. This trend seems to have supported the developing policy focus on the socio-economic wellbeing of the Park's local communities, and also to have encouraged sustainable tourism and sustainable development as organising frameworks. These policies were reciprocally inter-related and mutually constituting, and they appear to have co-evolved [5].

\subsection{Co-evolution between governance changes and sustainable tourism}

In both case studies over the study period, evidence of co-evolutionary relationships between sustainable tourism policies and broader governance changes not directly concerned with tourism are revealed. 
In the Lake District, the North West Regional Development Agency (a body with a strong remit to development regional economic strategies for the North West of England), provided funding to the Lake District Park Authority, to which the park authority emphasised they were keen 'to play an active part in the delivery of the regional and local strategies' developed by the North West Regional Development Agency through its associated Cumbria Tourism organisation, and to help these agencies to deliver sustainable tourism [27]. Here sustainable tourism co-evolved in connection with wider changes in governance arrangements [14].

Decreasing public sector funding through further governance changes (RDA's were later abolished under new governments) during the period, Park Authorities and government agencies were encouraged to work more closely together with local communities and businesses [15] re-emphasising the trends towards partnership working and community engagement and coinciding with sustainable development. Again, these policy trends were compatible with sustainable tourism and co-evolved with changes in wider governance approaches. Similarly, the LDNPA had appreciated and accepted the role of tourism in the context of broader trends relating to economic restructuring and declining agricultural industries as one of potentially strengthening the rural economy. Here, park policies may be viewed as co-evolving with these broader economic trends.

\subsection{Co-evolution between path dependence trajectories and path creating trajectories}

In the case study of the Peak District National Park, analysis revealed potential co-evolution between path dependent and path creating trajectories.

Longstanding governance trends in the UK towards to greater encouragement of participation by local communities perhaps led to institutions forming a path dependent trajectory. In the Peak District, Bramwell and Cox [15] argued that institutional arrangements in the Peak District National Park authority, were following a 'growing orthodoxy of deliberate governance in the UK' and that this in turn reflected a 'self-reinforcing' trajectory of path dependence [28]. In this case the Stanage Forum Steering group (a collaborative partnership, initiated by the PDNPA which included key user groups for the Stanage area of the Peak District) was developed in part due to the broader governance trend of Local Agenda 21 , which advocated inclusionary approaches to working with stakeholders in policy making to ensure the promotion of sustainable development.

This path dependent trend at international and national scales was also becoming evident for the Park Authority. Local Agenda 21 (LA21) ideas were included, for example, in the Park's Management Plan for 2000-2005 [24], which explained: "LA21 is the process by which the people in many countries are now helping to define a vision for the 21 st century, promoting sustainable development. The process seeks to involve as many people as possible, looking at problems and opportunities and drawing up an action plan".

The Stanage estate manager (who facilitated the partnership and the steering group) also argued that the Forum and Steering Group were influenced by Local Agenda 21 ideas about "getting people involved locally in their environment".

As well as long term trends towards greater participation from national and global policy, the inclusive and collaborative nature the Stanage Forum Steering Group represented a trajectory with path creative characteristics.

The appointment of the Stanage estate manager by the Peak District Park Authority in 1996, was required to develop a new management plan. This new manager represented change because he sought substantial engagement in decision-making by interested parties to diffuse previous conflicts around the estate's management of recreation, tourism and environmental protection. Additionally, involvement of an advisor working with the estate 
manager who was a recreational user of the area as well as a university academic with research interests in inclusive forms of consensus-building in environmental management. This advisor encouraged the new estate manager to use consensus-building environmental management ideas.

Stanage's unexpected new institutional arrangements reflected the two path-creating catalysts outlined here, but they also resulted from dialectical, co-evolving and coconstituting relationships between both path creation and path dependence [11], [12], [29]. The path-creating step of setting up the Forum and Steering Group in 2000, for example, was in dialectical relationship with an established, path dependent trend in the 1990s in the UK toward more participatory governance [30].

\section{CONCLUSION}

The findings of the research identify several scenarios of co-evolution in the context related to protected areas and sustainable tourism. Firstly, sustainable development policies coevolved with other broader policies that were directly related to sustainable tourism. These included interconnected aims around socio-economic development for communities in the protected areas. In this instance co-evolution of the sustainable development policies and sustainable tourism policies, occurred gradually and incrementally over a 15-year period [14] and perhaps was developmental 'necessity' for the improvement and maintenance of the ecological and social systems apparent in a protected area [6].

Historical conflicts and broader policies combined all played a role in promoting a desire for greater actor engagement and socio-economic well-being. This led to a greater engagement by the local business community, who advocated policies linked to socioeconomic well-being through developing the tourism industry in sustainable manner. Thus, the Park Authority's tourism-related policies could co-evolve in relation to wider pressure for better relationships between the Authority and community and business actors. The findings provided evidence for policies and actions that were co-evolving in a reciprocal and inter-related manner [7]. Similarly, governance changes on a national level influenced the development and changes relating to sustainable tourism. Initial increase to funding from external agencies encouraged engagement to work with others on developing sustainable tourism, leading to co-evolution with wider governance arrangements. A later decrease in external funding highlighted a need to continue efforts to work with local communities and in partnership. This further reflects how sustainable tourism co-evolved with wider governance approaches. It also echoes Noorgard's [6] assertions that co-evolutionary perspectives allow for 'theoretical pluralism' between differing economic and ecological paradigms.

Influences and policies towards trends for sustainable development, greater economic well-being and community engagement have in turn resulted in greater traction for sustainable tourism. On closer inspection, co-evolution is apparent in the development, promotion and continuation of sustainable tourism activities in protected areas. Co-evolution also provided a perspective that saw the combination of a path dependent and path creating trajectory within a tourism institution, rather than separate distinct categories as noted in other studies [11], [12], [18].

Unpicking when and where co-evolution happens and occurs is a difficult aim. Deciphering whether sub-systems are acting independently, shaping each other or determining the character requires careful consideration and not every interaction is coevolution [7].

However, despite its intricate approach to understanding trajectories, co-evolution has significant value to greater understanding contexts where 'societal beliefs' are substantial, 
such as the protected area context, and where sustainable development is being applied in governance [5]. Subsequently, adopting co-evolutionary perspectives to instances where sustainable tourism is increasingly important, could provide a fertile ground for those wanting to understand how and why destinations, institutions and governance make decisions and create policies in move towards certain paths.

\section{REFERENCES}

[1] Beresford, M. \& Phillips, A., Protected landscapes: A conservation model for the $21^{\text {st }}$ Century. The George Wright Forum, 17(1), pp. 15-26, 2000.

[2] Hanna, K., Clark, D. \& Slocombe, S. (eds), Transforming Parks and Protected Areas: Policy and Governance in a Changing World. Routledge: London, 2008.

[3] Sharpley, R. \& Pearce, T., Tourism, marketing and sustainable development in the English National Parks: The role of national park authorities. Journal of Sustainable Tourism, 15(5), pp. 557-573, 2007.

[4] MacLellan, R., A future model for protected areas and sustainable tourism development: The new national parks in Scotland. Protected Areas and Regional Development in Europe: Towards a New Model for the $21^{\text {st }}$ Century, ed. I. Mose, Ashgate: Aldershot, pp. 179-197, 2007.

[5] Kemp, R., Loorchach, D. \& Rotmans, J., Transition management as a model for managing processes of co-evolution towards sustainable development. International Journal of Sustainable Development \& World Ecology, 14(1), pp. 78-91, 2007.

[6] Norgaard, R., Coevolutionary development potential. Land Economics, 60, pp. 160173, 1984.

[7] Von Tunzelmann, N., Historical co-evolution of governance and technology. Paper presented at The Future of Innovation Studies, Eindhoven University of Technology, 20-23 Sep., 2001.

[8] Brouder, P., Anton Clavé, S., Gill, A. \& Ioannides, D., Why is tourism not an evolutionary science? Understanding the past, present and future of destination evolution. Tourism Destination Evolution, eds P. Brouder, S. Anton Clavé, A. Gill \& D. Ioannides, London: Routledge, pp. 1-18, 2017.

[9] Ma, M. \& Hassink, R., An evolutionary perspective on tourism area development. Annals of Tourism Research, 41, pp. 89-109, 2013.

[10] Brouder, P. \& Eriksson, R., Tourism evolution: On the synergies of tourism studies and evolutionary economic geography. Annals of Tourism Research, 43, pp. 370-389, 2013.

[11] Gill, A. \& Williams, P., Contested pathways towards tourism-destination sustainability in Whistler, British Columbia: An evolutionary governance model. Tourism Destination Evolution, eds P. Brouder, S. Anton Clavé, A. Gill \& D. Ioannides, Routledge: London, pp. 43-64, 2017.

[12] Sanz-Ibáñez, C. \& Anton Clavé, S., The evolution of destinations: Towards an evolutionary and relational economic geography approach. Tourism Geographies, 16(4), pp. 563-579, 2014.

[13] Brouder, P. \& Fullerton, C., Exploring heterogeneous tourism development paths: Cascade effect or co-evolving in Niagara? Scandinavian Journal of Hospitality and Tourism, 15(1-2), pp. 152-166, 2015.

[14] Bramwell, B. \& Mellon, V., Protected area policies and sustainable tourism: influences, relationships and co-evolution. Journal of Sustainable Tourism, 24(10), pp. 1369-1386, 2016. 
[15] Bramwell, B. \& Cox, V., Stage and path dependence approaches to the evolution of a national park tourism partnership. Journal of Sustainable Tourism, 17(2), pp. 191-206, 2009.

[16] Lake District National Park Authority, History of the National Park. www.lakedistrict.gov.uk/aboutus/nat parks history. Accessed on: 14 Jun. 2014.

[17] PDNPA (Peak District National Park Authority), Stanage/North Lees Estate Management Plan. Summary. Peak District National Park Authority: Bakewell, 2002.

[18] Connelly, S., Miles, T. \& Richardson, T., Legitimacy, deliberative arenas and the new rural governance. Paper presented at XI World Congress of Rural Sociology, Trondheim, Norway, Aug. 2004.

[19] Connelly, S., Miles, T. \& Richardson, T., Situated legitimacy: Deliberative arenas and the new rural governance. Journal of Rural Studies, 22(3), pp. 267-277, 2006.

[20] Richardson, T., Evaluation of the Stanage Forum, Draft. Department of Town and Regional Planning, University of Sheffield: Sheffield, 2005.

[21] Richardson, T. \& Connelly, S., Locating consensus: Living with power. Paper presented at the Planning Theory Conference. Oxford Brookes University: Oxford, Jun. 2001.

[22] Miles, M. \& Huberman, A., Qualitative Data Analysis: An Expanded Sourcebook. Sage: London, 1994.

[23] Lake District National Park Authority, National Park Management Plan. Lake District National Park Authority: Kendal, 2004.

[24] PDNPA (Peak District National Park Authority), National Park Management Plan, Strategy 2000-2005. Peak District National Park Authority: Bakewell, 2000.

[25] Lovelock, B., Why it's good to be bad: The role of conflict in contributing towards sustainable tourism in protected areas. Journal of Sustainable Tourism, 10(1), pp. 530, 2002.

[26] Lake District National Park Authority, A Plan for the National Park. Lake District National Park Authority: Kendal, 1998.

[27] Lake District National Park Authority, Promoting Sustainable Tourism. Lake District National Park Authority: Kendal, 2005.

[28] Mahoney, J., Path dependence in historical sociology. Theory and Society, 29(4), pp. 507-548, 2000.

[29] Garud, R. \& Karnøe, P., Path creation as a process of mindful deviation. Path Dependence and Creation, eds R. Garud \& P. Karnøe, Lawrence Erlbaum: London, pp. 1-38, 2001.

[30] Bramwell, B., Governance, the state and sustainable tourism: a political economy approach. Journal of Sustainable Tourism, 19(4-5), pp. 459-477, 2011. 